\title{
EDITORIAL
}

\section{To Rule or Not to Rule: Part Two}

The simplistic ideas about the judicial function in international relations are very harmful to the public perception of the role of the International Court of Justice. [...] The general public both expects too much of the Court, and is then disappointed that there is so much violence in the world which the Court does not seem to be effective to control. ${ }^{1}$

In an earlier issue, our journal commented on recent predestined "disastrous legal expeditions" by states to the International Court of Justice. It was concluded that "this political use of the Court is an irritating side effect of the welcome increase in the recourse to the Court." One of the cases commented upon in that context was the Bosnia-Herzegovina case, a case in which an important third step was taken by the Court on 11 July $1996{ }^{3}$ After two rulings on the indication of provisional measures in $1993,{ }^{4}$ the Court has now given itself jurisdiction to rule on the merits of the case. Apparently, recourse to the Court by Bosnia-Herzegovina was not as disastrous as some had predicted. The World Court can now seriously examine Bosnia's claim that the Federal Republic of Yugoslavia (i.e., Serbia and Montenegro; hereinafter FRY) has taken part in, or, at the very least, has not done what it should have done to prevent, genocide from taking place against Bosnia's Moslem population.

Whether the international community as it is now organized is capable

1. R.Y. Jennings, The Proper Work, and Purposes of the International Court of Justice, in A.S. Muller, D. Raič \& J.M. Thuránszky (Eds.), The International Court of Justice: Its Future Role After 50 Years, para. 3 (1996).

2. R. Lefeber, To Rule or Not to Rule, 8 LJIL 246, at 247 (1995).

3. Application of the Convention on the Prevention and Punishment of the Crime of Genocide (Bosnia and Herzegovina v. Federal Republic of Yugoslavia (Serbia and Montenegro)), Judgment on preliminary objections of 11 July 1996 (not yet published).

4. See Application of the Convention on the Prevention and Punishment of the Crime of Genocide (Bosnia and Herzegovina v. Federal Republic of Yugoslavia (Serbia and Montenegro)) (Provisional Measures), Order of 8 April 1993, 1993 ICJ Rep. 11, and Order of 13 September 1993, 1993 ICJ Rep. 325.

Leiden Journal of International Law 9: 265-271, 1996. 
of any serious, acute action to prevent genocide, or at least to punish those who have actively taken part in it, is a matter which will not be looked at here. The record shows that its political will to intervene and enforce are minimal. What is relevant here is the fact that the international community formulated a set of standards in 1948 concerning horrific crimes of genocide, and that the Court has now found it has jurisdiction to help maintain those standards. It has ruled that it can examine the question of whether the FRY has violated the norms laid down in the Genocide Convention and what the consequences of such an alleged violation should be. In reaching its decision, the Court has provided onlookers with a small glimpse into its chambers and the 'inner forces' that shape decisions of the present Court.

The Court ruled that its jurisdiction was based only on Article IX of the Genocide Convention. ${ }^{5}$ Essentially, that was an affirmation of its earlier rulings concerning the provisional measures that had been requested by Bosnia-Herzegovina in $1993 .{ }^{6}$ The specific nature of the Genocide Convention, and its object and purpose, played a large role in the Court's interpretation of the rules and the facts. Citing from its 1951 Advisory Opinion on reservations to the Convention, the Court stated that the horrendous crime that the Convention seeks to prevent, or at least to punish, does not require a perfect contractual balance between the parties. The Court found that the rights and obligations that are contained in the Convention have an erga omnes character.' This point of departure gave the Court more room to manoeuvre than it may otherwise have had.

Ratione personae, the Court did not dwell extensively on modalities of treaty succession (for instance, does an automatic succession rule exist as regards a fundamental human rights treaty such as the Convention?). Bosnia was a party to the Convention at the time of the filing of the Application on 20 March 1993, and that was considered the determining factor. ${ }^{8}$ Neither did it devote any attention to the controversies surroun-

5. Other grounds for jurisdiction had been brought forward by Bosnia-Herzegovina in the requests for provisional measures of March and May 1993. See Bosnia-Herzegovina case, Orders, supra note 4.

6. Bosnia-Herzegovina case, Orders, supra note 4.

7. Reservations to the Convention on the Prevention and Punishment of the Crime of Genocide, Advisory Opinion, 1951 ICJ Rep. 23 et seq.

8. Bosnia-Herzegovina case, Judgment, supra note 3, at para. 26. 
ding the FRY's membership in the UN, the same controversies to which it had devoted various paragraphs in its Order of 8 April 1993. ${ }^{9}$ Ratione materiae, the Court saw no territorial limitation in the application of the Convention, nor did it see a limitation connected with a particular type of conflict - internal or international. ${ }^{10}$ Ratione temporis, the Court concluded that it had jurisdiction over the relevant events that have occurred "since the beginning of the conflict". ${ }^{11}$

The most difficult part of the Court's judgment was its reply to the FRY's preliminary objection regarding the notion of state responsibility, as used in Article IX. Yugoslavia maintained a more restrictive interpretation of the responsibilities a state could incur from the Convention. In its opinion, the Convention's primary norms were directed more at individuals than at states. Bosnia-Herzegovina, on the other hand, essentially argued that the Convention established both an individual responsibility and a responsibility on the part of states to do everything possible to prevent, or at least punish, genocide. While stressing the erga omnes character of the rights and obligations of the Convention, the Court concluded that:

the reference in Article IX to "the responsibility of a State for genocide or for any of the other acts enumerated in Article III", does not exclude any form of State responsibility. ${ }^{12}$

It is on this point that the ruling of the Court shows a most significant parting of ways. Judges Oda, Shi, Vereshchetin, and Kreca disagreed strongly with their colleagues in two respects. First, the impression is given from their individual opinions that they did not think the Court could 'decide to decide' to rely so heavily on the object and purpose of the Convention when tackling the interpretative question before it. Second, they gave a more restrictive interpretation of the disputed provision; they tie the Court more strongly to the text of the Convention. According to Judge Oda's understanding of the Convention:

9. Bosnia-Herzegovina case, Order of 8 April 1993, supra note 4, at 14 .

10. Bosnia-Herzegovina case, Judgment, supra note 3, para. 31.

11. Id., para. 34 .

12. Id., para. 32. The Court went on to note: "[n]or is the responsibility of a State for acts of its organs excluded by Article IV of the Convention, which contemplates the commission of an act of genocide by 'rulers' or 'public officials'. Article IV reads as follows: 'Persons committing genocide or any of the other acts enumerated in article III shall be punished, whether the are constitutionally responsible rulers, public officials or private individuals'." 
[t]he failure of any Contracting Party "to prevent and punish" such a crime [the international crime of genocide] may only be rectified and remedied through (i) resort to a competent organ of the United Nations (Art. VIII) or (ii) resort to an international penal tribunal (Art. VI), but not by invoking the responsibility of States in inter-State relations before the International Court of Justice. ${ }^{13}$

This strong difference of opinion lays bare what is perhaps the softest spot and most vulnerable part of the Court's ruling. It exemplifies a struggle in the Court between two opposing attitudes towards the role of the law. Without wanting to stigmatize, the two camps may called the 'ruleoriented' camp and the 'policy-oriented' camp. In somewhat simplistic terms, the former group views the function of law and the role of the Court in a positivistic manner, whereby the role of the Court is servile and more distanced from the case before it. Judge Oda seems to stand out as one the members of this school. The advocates of the latter school go somewhat beyond that, and allow the law a little more leeway to pioneer and re-interpret itself in accordance with a more elementary sense of what is 'good' and what is 'bad', and what is in line with the needs of a particular time frame or situation. Their approach is goal oriented, whereby the goal can be defined in a wider context than a strictly legal framework. ${ }^{14}$ Judge Weeramantry is a clear disciple of this line of thought, and the main thrust of their view in this case clearly prevailed for most of the judges. A silent majority of the Court was convinced, or at least not opposed to the

13. According to Oda, Bosnia-Herzegovina "would have had to show that Yugoslavia has breached the rights of Bosnia-Herzegovina as a Contracting Party (which by definition is a State) that should have been protected under the Convention" (emphasis added). He goes on to say that "Yugoslavia might have been responsible for certain instances of genocide or genocidal acts committed by its public officials or surrogates in the territory of BosniaHerzegovina, but this fact alone does not mean that there is a 'dispute' between the States relating to the responsibility of a State, as Yugoslavia did not violate the rights bestowed upon Bosnia-Herzegovina by the Convention". Bosnia-Herzegovina case, Judgment, supra note 3, para. 6 (Judge Oda, Declaration).

14. A similar dichotomy could be seen in the 1951 Advisory Opinion on reservations to the Genocide Convention. The majority of the Court was of the opinion that " $[t]$ he solution of [the problem before the Court] must be found in the special characteristics of the Genocide Convention." Reservations case, supra note 7, at 23. However, Judges McNair, Read, and Hsu Mo argued that: "[i]t is [...] not universality at any price that forms the first consideration". They concluded that the Convention and its purposes deserve "the most generous interpretation; but [it] is an instrument which is intended to produce legal effects by creating legal effects between the parties to it, and we have therefore felt it necessary to examine it against the background of law”. Id., at 47 (Judges McNair, Read, and Hsu Mo, Joint Dissenting Opinion). 
idea, that the fundamental aim of the Convention, i.e., the prevention and punishment of one of the gravest crimes imaginable, could function as a decisive background against which Article IX, and the role that the Court sees for itself in that Article, was to be held.

The object and purpose of the Genocide Convention are clear: "to liberate mankind from such an odious scourge", which has "inflicted great losses on humanity". ${ }^{15}$ These are strong words, for which the intentions resonate deeply in every sane human being. However, the fundamental character of the provisions of the Genocide Convention also presents one of the central dilemmas that is 'baked into' the present case: how far can one go in interpreting the law in relation to a heartfelt feeling of what is good and bad?

In two other rulings, which were rendered by the Court in the very same week as the Bosnia-Herzegovina ruling on jurisdiction, the balance seems to have tilted in another direction, if it can be said that any balance was found in those cases at all.

The Court declined jurisdiction in an advisory opinion requested by the World Health Organization (WHO) on the use of nuclear weapons, on the ground that the question raised did not fall "within the scope of [the] activities" of the organization in question as defined by its constituent instrument. ${ }^{16}$ Here, Judge Shahabuddeen, and more so Judges Weeramantry and Koroma, disagreed strongly with the Court's decision. According to Judge Weeramantry, the object and purpose of the WHO Constitution had not been sufficiently taken into account. ${ }^{17} \mathrm{He}$ is cited in the Court's Press Communiqué as saying that: " $[t]$ he Court's decision was based on restricted principles of treaty interpretation and should rather have interpreted the WHO's Constitution in the light of its object and purpose". As to the question posed by the United Nations General Assembly on the threat or use of nuclear weapons, the Court did acknowledge its jurisdiction. ${ }^{18}$ The somewhat puzzling substantive ruling that followed,

15. See, respectively, paras. 3 and 2 of the Preamble of the Convention on the Prevention and Punishment of the Crime of Genocide, 78 UNTS 277 (1951).

16. Legality of the Use by a State of Nuclear Weapons in Armed Conflict (World Health Organization), Advisory Opinion of 8 July 1996 (not yet published). See ICJ Press Communiqué No. $96 / 22$ of 8 July 1996 , at 6 .

17. Id., Annex, at 3 .

18. Legality of the Threat or Use of Nuclear Weapons (General Assembly of the United Nations), Advisory Opinion of 8 July 1996 (not yet published). See ICJ Press Communiqué 
however, shows that neither the formalist nor the pragmatist camp were able to firmly convince their colleagues. Both the President of the Court, Bedjaoui, and Judge Guillaume voted in favour of the ruling that neither customary nor conventional international law contain a universal prohibition of the threat or use of nuclear weapons. The President, however, attached a declaration, in which he stated that the ruling must not be "interpreted as leaving the way open to the recognition of the lawfulness of the threat or use of nuclear weapons". ${ }^{19}$ Judge Guillaume, on the other hand, concluded from the Courts's judgment that the Court "has recognized the legality of policies of deterrence".$^{20}$ To add to the confusion, the Court decided, with seven votes to seven and the President casting the deciding vote, that it could not give a straight answer to the question whether the threat or use of nuclear weapons was contrary to international law or not.

The visibility of the two schools of thought, and the struggle for the middle ground they share between them, gives us a small insight into the inner workings of the present Court and the different worlds of which it is made up. In the Bosnia-Herzegovina case, and even as regards the advisory opinion requested by the WHO, common ground could be found. The question posed by the General Assembly, however, resulted in a resourcefully constructed compromise that satisfied nobody and everybody. It is a brilliantly devised 'way out', but, from a legal perspective, perhaps that is just about all that it is.

Why was it possible to find sufficient middle ground in the BosniaHerzegovina case, while it was not possible in the Nuclear Weapons ruling delivered four days earlier? The explanation for that must be found in the intricacies of each of the cases and the nature of the questions brought before the Court. The Bosnia-Herzegovina case was, to a large degree, a case of treaty interpretation. Therefore, the Court operated within a structured framework, whose ambiguities it could fill in with the help of the framework as a whole. The same can be said, although to a lesser degree, of the WHO request. There, the WHO Constitution offered the delineated area within which the question could be examined. That element was totally

No. $96 / 23$ of 8 July 1996.

19. Id., Annex, at 1 .

20. Id., Annex, at 3. 
missing in the General Assembly request. And that, from a legal point of view, should have precluded the Court from answering this question.

Rule-oriented or goal-oriented lawyer, the Court has a function to perform. A definition of the middle ground that should be looked for was formulated by the late Judge Lachs in his separate opinion to the Nicaragua merits judgment:

It is not the purely formal aspects that should in my view be decisive, but the legal framework, the efficacy of the solution that can be offered, the contribution the judgement may make to removing one more dispute from the overcrowded agenda of contention the world has to deal with today. ${ }^{21}$

The Bosnia-Herzegovina case offered a clear legal framework within which rule-oriented and goal-oriented lawyers could battle for dominance. To a large degree, so did the WHO request on the legality of the use of nuclear weapons. The General Assembly request for an advisory opinion was asking too much of the Court. There was no clear legal framework, no chance of any efficate solution and, most certainly, no contribution to make to removing a dispute from the world's overcrowded agenda of today.

A.S. Muller

21. Military and Paramilitary Activities in and Against Nicaragua (Nicaragua v. United States of America) (Merits), Judgment, 1986 ICJ Rep. 168. 